\title{
PROCJENA BONITETA KORIŠTENJEM MODELA SINERGIČNE PRIMJENE KVALITATIVNIH I FINANCIJSKIH POKAZATELJA
}

\author{
Stručni rad / Professional Paper \\ UDK/UDC: $658.14 / .17$ \\ DOI: $10.51650 /$ ezrvs. $15.3-4.12$ \\ Primljeno / Received: $7 / 6 / 2021$ \\ Prihvaćeno / Accepted: 3/9/2021
}

\begin{abstract}
Općepoznato je da se u hrvatskom gospodarstvu vrlo malo pažnje pridaje analizi poslovanja i upravljanju poslovnim rizicima. Također, nekompetentnost i neadekvatna stručnost top menadžmenta, te površni i nedovoljno stručni nadzor poslovanja od strane vlasnika kontinuirano generiraju nelikvidnost, prezaduženost i gubitke u poslovanju. Nerješavanje (pravovremeno) navedenih problema je u konačnici uzrok velikog broja stečajeva, te likvidacija poslovnih subjekata, a što u konačnici stvara i ozbiljne probleme hrvatskom gospodarstvu kao cjelini. U ovom radu izvršit će se analiza poslovanja odnosno poslovnih rizika grupe Uljanik d.d. tijekom 2016. i 2017. godine, te utvrditi bonitet društva u tom trenutku odnosno prije objave stečaja društva u 2019. godini. Radom će se nastojati utvrditi jesu li se poteškoće u poslovanju mogle pravovremeno prepoznati, te je li temeljem procjene boniteta društva i spoznaja dobivenih tijekom analize, upravljačka struktura društva u spomenutom periodu mogla brže i odlučnije reagirati. U procjeni boniteta koristit će se optimalan izbor financijskih i kvalitativnih pokazatelja pomoću kojih je moguće donijeti pouzdaniju ocjenu boniteta uvažavajući unutarnje i vanjske čimbenike koji utječu na poslovanje društva. U modelu procjene u ovom radu konačna ocjena boniteta utvrđuje se sintezom i zajedničkim bodovanjem financijskih i kvalitativnih pokazatelja, te pruža sveobuhvatnu i vjerodostojniju informaciju o poslovnom subjektu i njegovim rizicima u poslovanju i na taj način omogućava donošenje pravodobnih i ispravnih poslovnih odluka.
\end{abstract}

Ključne riječi: Uljanik d.d., procjena boniteta, financijski pokazatelji, kvalitativni pokazatelji, analiza poslovanja.

\section{Uvod}

Informacija o bonitetu nužna je pretpostavka donošenja kvalitetnih poslovnih odluka. U znanstvenoj i poslovnoj praksi izraz bonitet izražava vrijednost, pouzdanost, poslovnu i kreditnu sposobnost poslovnog subjekta.

$\overline{1 \text { Istarsko veleučilište, }}$ Pula; e-mail: avaresko@gmail.com 
Procijeniti bonitet trgovačkog društva, znači procijeniti njegovo "zdravlje“, sposobnost da dugoročno preživi (Leko, 1996: 10). Rizik poslovanja, procjena boniteta i analiza poslovanja trebali bi biti nezaobilazni pojmovi u svakodnevnom poslovanju svakog trgovačkog društva, a posebice onih velikih sa složenim poslovnim procesima. Jedan od motiva procjene boniteta je procjena sadašnjih i budućih poslovnih rizika društva. Veći rizik i loša ocjena rejtinga nalaže bržu reakciju i poduzimanje odlučnih, pa i oštrih mjera za njegovo otklanjanje.

Temeljem podataka iz bilance i pokazatelja koji iz njih proizlaze možemo utvrditi kako je trgovačko društvo poslovalo u prošlosti i koliko uspješno. No, ti podaci nam govore vrlo malo o menadžmentu, tržišnom udjelu, proizvodnim kapacitetima, organizaciji poslovanja itd. i zapravo ništa o smjeru u kojem se društvo razvija.

S obzirom na složenost poslovanja poslovnog subjekta, te važnosti mnogih internih $i$ eksternih čimbenika koji mogu na odgovarajući način utjecati na poslovanje društva, nameće se nužnost korištenja odgovarajuće metodologije pri ocjeni boniteta koja će pored financijskih pokazatelja, na primjeren način vrednovati i utjecaj vanjskih odnosno nefinancijskih čimbenika i tako doprinijeti pouzdanijoj ocjeni boniteta. Pokazatelji se formiraju i računaju upravo zbog toga da bi se stvorila informacijska podloga potrebna za donošenje određenih odluka (Žager i Žager, 1999: 172).

\section{Aspekti procjene boniteta i pregled dosadašnjih istraživanja}

Čak i ako podaci iz bilance ukazuju na nesmetano obavljanje djelatnosti društva, utjecaj vanjskih čimbenika može vrlo brzo dovesti poslovanje društva u ozbiljne poslovne probleme $i$ isto osuditi na propast. Samim razvojem financijskih tržišta i instrumenata financijskog zaduživanja u Hrvatskoj, raste i važnost procjene boniteta u svakodnevnom poslovanju.

Uključivanjem financijskih i kvalitativnih pokazatelja u konačnu ocjenu boniteta trgovačkog društva, dobiva se kvalitetnija i potpunija slika poslovanja društva koja pored standardnih financijskih pokazatelja ukazuje i na ostale čimbenike koji neposredno utječu na poslovanje društva, a u konačnici i na ostvarenje financijskog rezultata (ECB, 2010).

$\mathrm{U}$ okviru procjene poduzetnika u ovom radu, sustavno se uzimaju u obzir putem kvalitativnog rejtinga, koji zajedno s važećim financijskim rejtingom daje konačni rejting. Uzimajući u obzir ostale faktore (management, vlasničku strukturu, kvalitetu postrojenja i organizaciju, tržišni položaj) doznajemo konačni rejting poduzetnika.

Prilikom određivanja konačne ocjene boniteta najčešće se odabire pet kategorija kvalitativnih i financijskih čimbenika kojima se dodjeljuju pripadajući ponderi na temelju njihove važnosti u postojećoj literaturi, te važnosti kojom utječu na poslovni rezultat društva (Altman, 2008).

Tematika utvrđivanja boniteta i analize poslovanja je u domaćoj literaturi samo djelomično istražena i obrađena od strane nekoliko autora. Prvi su počeli istraživati navedene teme Leko, V., Žager K., Pervan, I., Kopun, V., dok se u proteklih 10-ak godina istraživanjem navedenih tema bave i Vujević, l., Vidučić, Lj. i Aljinović, B. Ž. Znanstveni i stručni radovi u Hrvatskoj orijentirani su i obrađuju najvećim dijelom uobičajene financijske pokazatelje, te su kvalitativni pokazatelji za ocjenu boniteta trgovačkog društva vrlo malo istraženi i gotovo zanemareni. $U$ većini radova obrađuje se horizontalna i vertikalna analiza, analiza trenda poslovanja, te pojedinačni i skupni pokazatelji financijske analize. $U$ pojedinim se radovima za procjenu boniteta koriste Altmanovog Z-score model, te Du pontov sustav pokazatelja. 
Z score model za izračun koristi kombinacije četiri do pet financijskih pokazatelja koji ponderirani određenim koeficijentom daju procjenu mogućnosti propasti poslovanja (Žager et al., 2008: 270). Du Pontov sustav koristi pokazatelje rentabilnosti poslovanja za potrebe planiranja budućeg poslovanja (Tintor, 2020). Zajedničko za oba modela je da ne uključuju kvalitativne čimbenike u procjeni boniteta.

U radu će se stoga osmisliti model ocjene boniteta koristeći kombinaciju financijskih i kvalitativnih pokazatelja, te će se uz odgovarajuće pondere pogodne za svaki pokazatelj doći do konačne ocjene boniteta i takvim modelom doprinijeti dosadašnjim znanstvenim istraživanjima.

\section{Prednosti i nedostaci modela procjene boniteta zajedničkom primjenom financijskih i kvalitativnih pokazatelja}

Modeli izražavaju ocjenu boniteta u vidu brojke koja izražava neku vrijednost. Uobičajeno se pokazateljima dodjeljuju određeni ponderi koji pokazuju kolika je važnost pojedinog pokazatelja u modelu.

Korišteni model za ocjenu boniteta bazira se na ponderiranim kvalitativnim i financijskim pokazateljima. Financijski pokazatelji su standardizirani i prikazani u točki 5.1. ovog rada dok se kvalitativni pokazatelji posebno prezentiraju u točkama 4. i 5.2.

Navedena metodologija opće je prihvaćena u razvijenim gospodarstvima svijeta, a najčešće se oslanjaju na metodologiju ocjene boniteta kojeg predlažu svjetski poznata konzultantska društva, od kojih je najraširenije američko konzultantsko društvo Standard \& Poor's. ${ }^{2}$

Najveća prednost modela je uključivanje u procjenu kvalitativnih čimbenika koji se ne mogu izračunati iz financijskih izvješća, a imaju značajan utjecaj na poslovanje svakog trgovačkog društva. Naime, pomoću kvalitativnih pokazatelja moguće je obuhvatiti širu sliku poslovanja koja uključuje i kvalitetu menadžmenta, vlasničku strukturu, organizaciju i proizvodni potencijal, tržišni udio i dr (Pavković i Vedriš, 2011).

Dodatna prednost je što predloženi model omogućava jednostavniju i kvalitetniju ocjenu boniteta malih i srednjih društava, te se isto tako lako i brzo prilagođava promjenama koje nastaju u okolini. Novi zakoni, novi konkurenti na tržištu, novi menadžment, nova vlasnička struktura, su čimbenici koji se kontinuirano mijenjaju i odražavaju se na uspješnost poslovanja svakog trgovačkog društva.

Osnovni nedostatak procjene boniteta korištenjem predloženog modela očituje se u subjektivnim kriterijima procjene kvalitativnih čimbenika od strane stručnjaka koji vrši procjenu i kao takav je specifičan za ocjenu boniteta u hrvatskoj gospodarskoj praksi, te nije namijenjen za korištenje u drugim zemljama.

Nedostatak se očituje i u činjenici da je za kvalitetnu procjenu nužan izravni kontaktu s drugom stranom odnosno menadžmentom društva za koji se utvrđuje bonitet. Naime, izravnim intervjuom moguće je najkvalitetnije ocijeniti vođenje tvrtke od strane menadžmenta, kvalitetu organizacije i potencijal proizvodnih kapaciteta, kvalitetu izvještavanja, strategiju budućeg poslovanja u odnosu na tržišnu poziciju i okruženje.

${ }^{2}$ Standard \& Poor's, američka konzultantska kuća čije su konzultantske usluge najraširenije u svijetu. Posluje više od 80 godina, te je ujedno i sinonim za nezavisnu i kvalitetnu ocjenu boniteta trgovačkih društava i banaka širom svijeta. 
Model je prvenstveno namijenjen za procjenu boniteta malih i srednjih društava, dok se za pouzdaniju procjenu velikih društava preporuča uključivanje većeg broja pokazatelja.

Upravo se to korištenje kvalitativnih pokazatelja i njihova prilagodba specifičnostima današnjih uvjeta koji vladaju na tržištu u Hrvatskoj doprinos istraživanju jer do sada ta tema u hrvatskoj znanosti nije još dovoljno istražena, a obzirom na sve češću primjenu ocjene boniteta, ista će poprimiti sve veću važnost u svakodnevnom poslovanju.

\section{Pregled kvalitativnih faktora i njihovi ponderi važnosti}

Prilikom određivanja kvalitativne ocjene u ovom radu uzet će se u obzir kvalitativni faktori s pripadajućim ponderima, a koji su istima dodijeljeni na temelju važnosti kojom utječu na poslovni rezultat društva i prikazani su u tablici broj 1.

Tablica 1. Kvalitativni faktori i njihovi ponderi

\begin{tabular}{|l|c|}
\hline Kvalitativni faktor & Ponder \\
\hline 1. Menadžment & $13 \%$ \\
2. Vlasnička struktura & $10 \%$ \\
3. Tržište i tržišni položaj & $8 \%$ \\
4. Proizvodni kapaciteti i grana djelatnosti & $9 \%$ \\
5. Računovodstvo i izvješćivanje & $5 \%$ \\
6. Pravna regulativa i sigurnost & $5 \%$ \\
\hline
\end{tabular}

Izvor: prilagođeno prema Vareško A. (2008), Utvrđivanje modela sinergične primjene sustava financijskih i kvalitativnih pokazatelja pri ocjeni boniteta trgovačkog društva, magistarski rad, Ekonomski fakultet Pula, Pula

Posebno će se ocjenjivati kvalitativni pokazatelji uvršteni u model, budući da su oni dodjeljuju temeljem prikupljenih informacija i subjektivnih procjena. Kvalitativni pokazatelji u modelu mogu se koristiti za bilo koju gospodarsku granu, a ponderi važnosti su im dodijeljeni temeljem specifičnosti uvjeta poslovanja u Republici Hrvatskoj.

Najveći ponder dan je menadžmentu odnosno kvaliteti i stručnosti uprave, jer je u poslovnoj praksi poznato da je kvalitetan partner ne samo onaj koji je u mogućnosti podmiriti svoje obveze, nego je to i voljan učiniti. Menadžment u najširem smislu obuhvaća upravljanje cjelokupnim poslovanjem društva s ciljem da se raspoloživi resursi optimalno koriste za ostvarenje najviše razine performansi.

Vlasničkoj strukturi dodijeljen je također značajan ponder. Važno je utvrditi da li je struktura vlasništva jasna i transparentna ili upitna, da li su u tijeku sudski sporovi, da li je prisutno prelijevanje gubitaka između društava u grupi, utvrditi pravog vlasnika ukoliko se radi o više križanja vlasništva između suvlasnika i dr. Rizik netransparentne vlasničke strukture može u konačnici dovesti do propasti tvrtke.

Tržišni položaj isto tako važan kvalitativni čimbenik, budući da veći udio na tržištu upućuje na jaču snagu nametanja uvjeta i diktiranja cijena. Pojedina društva poslužuju samo nekolicinu kupaca, dok druga poslužuju tisuće kupaca. Općenito, što društvo ima manje kupaca to je rizičnije njegovo poslovanje jer gubitak svakog kupca može dramatično utjecati na prihode. Također, veliki broj konkurenata u istom segmentu stvaraju teško okruženje za poslovanje. 
Prilikom dodjele pondera za proizvodne kapacitete i granu djelatnosti bolju ocjenu dobiva trgovačko društvo koje ima jasnu i efikasnu organizacijsku strukturu, te koristi suvremena, efikasna i visoko kvalitetna postrojenja i softverska rješenja, u odnosu na poduzetnika koji koristi zastarjelu tehnologiju čime mu je i produktivnost manja. U ovu kategoriju može se uključiti i rizik grane, a koji se ocjenjuje na temelju dostupnih statističkih podataka, iskustava vezanih uz analizu poslovanja pojedinih grana i njihovih cikličnosti, te u skladu s time su svrstane u rizične kategorije. U Hrvatskoj se najčešće kao najmanje rizične grane smatraju energetika, državne i financijske institucije, trgovina, dok se proizvodnja i brodogradnja smatraju rizičnijima.

Računovodstvo i izvješćivanje. Računovodstveni podaci moraju biti istiniti i točni. Kvalitetno računovodstvo je preduvjet za ispravne poduzetničke odluke.

Pravna regulativa i sigurnost pokazatelji su koji se u procjeni boniteta u hrvatskoj gospodarskoj praksi ne smiju nikako izostaviti, uzimajući u obzir i učestale promjene u pravnoj regulativi. Promatra se i da li pravna regulativa potiče ili koči poduzetništvo, zatim visina poreznog opterećenja, učestalost promjena zakona i sl.

Procjena korištenih financijskih i kvalitativnih faktora odvija se u načelu po rating sustavu ocjenjivanja od 1 (nedovoljno) do 5 (izvrsno) kako bi se dobiveni boniteti mogli nesmetano uspoređivati između društava različitih veličina i grana poslovanja (Grunert, Norden i Weber, 2005).

\section{Analiza pokazatelja poslovanja na primjeru grupe Uljanik d.d.}

\subsection{Analiza financijskih pokazatelja grupe Uljanik d.d. za 2016. i 2017. godinu}

Grupa Uljanik d.d stopostotni je ili većinski vlasnik 12 poduzeća, te je riječ o koncernu mora konsolidirati poslovanje svih svojih društava u jedinstvenom izvješću. Analizom financijskih izvješća grupe Uljanik d.d. dolazimo do spoznaja prezentiranih niže.

Tablica 2. Povrat na kapital

HRK

\begin{tabular}{|l|c|c|}
\hline Stavka/godina & $\mathbf{2 0 1 7}$ & $\mathbf{2 0 1 6}$ \\
\hline Neto dobit & -1.819 .681 & -173.028 \\
\hline Kapital i rezerve & -1.833 .622 & 20.164 \\
\hline Povrat na kapital & -1 & -1 \\
\hline
\end{tabular}

Izvor: izračun autora

Povrat na kapital (neto dobit/kapital i rezerve) je negativan i dobio je najnižu ocjenu 1 (jedan), budući da je društvo 2017. i 2016. godinu završilo s gubitkom u poslovanju. Što je veći iznos povrata na kapital to ukazuje na kvalitetnije poslovanje društva, u svakom slučaju treba biti pozitivan broj. U primjeru Uljanika d.d. isti ima negativnu vrijednost u obje godine. Trend kretanja povrata na kapital je dobio ocjenu 1 (jedan) jer je gubitak ostvaren u 2016. i 2017. godini. 
Tablica 3. Profitabilnost

HRK

\begin{tabular}{|l|c|c|}
\hline Stavka/godina & $\mathbf{2 0 1 7}$ & $\mathbf{2 0 1 6}$ \\
\hline Poslovni prihodi & 1.994 .953 & 1.930 .765 \\
\hline EBIT & -1.712 .323 & -64.560 \\
\hline Profitabilnost & $-0,85$ & $-0,03$ \\
\hline
\end{tabular}

Izvor: izračun autora

Profitabilnost odnosno operativna marža (ebit/poslovni prihodi) je negativna zbog negativnog rezultata poslovanja u

2017. i 2016. godini, te je dobilo ocjenu 1 (jedan). Trend istog pokazatelja je negativan zbog značajnog povećanja gubitka u 2017. godini, te je samim time došlo do pogoršanja pokazatelja. Ovaj omjer pokazuje profitabilnost operativnog poslovanja prije troška kamata i poreza.

Tablica 4. Odnos novčanog toka i poslovnih prihoda

HRK

\begin{tabular}{|l|c|c|}
\hline Stavka/godina & $\mathbf{2 0 1 7}$ & $\mathbf{2 0 1 6}$ \\
\hline Novčani tok od poslovnih aktivnosti & -214.558 & -753.325 \\
\hline Poslovni prihodi & 1.994 .953 & 1.930 .765 \\
\hline Novčani tok/poslovni prihodi & $-0,10$ & $-3,88$ \\
\hline
\end{tabular}

Izvor: izračun autora

Tok novca kao pokazatelj odnosa novčanog toka od poslovnih aktivnost i prodaje (novčani tok/poslovni prihodi) je negativan i dobio je najnižu ocjenu 1 (jedan) kako u 2017. godini tako i u 2016. Trend je stabilan jer se negativni novčani tok u 2017. smanjio u odnosu na 2016. godinu.

Tablica 5. Odnos duga i kapitala

HRK

\begin{tabular}{|l|c|c|}
\hline Stavka/godina & $\mathbf{2 0 1 7}$ & $\mathbf{2 0 1 6}$ \\
\hline Ukupne obveze & 4.788 .508 & 4.065 .381 \\
\hline Kapital i rezerve & -1.833 .662 & 20.164 \\
\hline Odnos duga i kapitala & $-2,61$ & 201 \\
\hline
\end{tabular}

Izvor: izračun autora

Odnos duga i vlastitog kapitala izračunava se na način da se ukupne obveze podijele ukupnim vlastitim kapitalom. Poželjna vrijednost je 1:1 odnosno manja od 1 i veća od 0 . Vjerovnici i investitori smatraju tvrtke s višim omjerom duga i kapitala rizičnijima od onih s nižim omjerom. Pokazatelj zaduženosti iznosi -2,61 u 2017. godini, te 201 u 2016. godini. Navedeno ukazuje da društvo iz vlastitih sredstava nije u mogućnosti financirati ni najmanji iznos preuzetih obveza (duga). Za obje godine društvo je dobilo najnižu ocjenu 1 (jedan) s negativnim trendom budući je pokazatelj čak negativan u 2017. godini. 
Tablica 6. Likvidnost

HRK

\begin{tabular}{|l|c|c|}
\hline Stavka/godina & $\mathbf{2 0 1 7}$ & $\mathbf{2 0 1 6}$ \\
\hline Kratkoročne obveze & 3.647 .393 & 3.323 .149 \\
\hline Kratkotrajna imovina & 1.572 .562 & 2.396 .276 \\
\hline Koeficijent likvidnosti & 0,43 & 0,72 \\
\hline
\end{tabular}

Izvor: izračun autora

Likvidnost je u 2017. godini iznosila 0,43, a u 2016. godini 0,72. Za likvidnost je društvu također dodijeljena najniža ocjena jedan budući je obje godine koeficijent likvidnosti bio manji od 0,85 , te je trend također bio negativan jer se likvidnost tijekom 2017. godine dodatno pogoršala u odnosu na prethodnu godinu.

Tablica 7. Kamatno pokriće

HRK

\begin{tabular}{|l|c|c|}
\hline Stavka/godina & $\mathbf{2 0 1 7}$ & $\mathbf{2 0 1 6}$ \\
\hline Operativna dobit & -1.712 .323 & -64.560 \\
\hline Kamatni rashodi & 117.173 & 104.713 \\
\hline Kamatno pokriće & -1 & -1 \\
\hline
\end{tabular}

Izvor: izračun autora

Pokriće kamata pokazuje omjer operativne dobiti i kamatnih rashoda i dobili najnižu ocjenu 1 (jedan) za obje promatrane godine. Navedeni pokazatelj je negativan zbog negativnog operativnog gubitka (EBIT) ostvarenog u obje promatrane godine, te je društvo dobilo najnižu ocjenu. Trend je također negativan jer se operativni gubitak iz poslovanja povećava u 2017. u odnosu na 2016. godinu.

\subsection{Analiza kvalitativnih pokazatelja grupe Uljanik d.d. za 2016. i 2017. godinu}

\subsubsection{Menadžment kvaliteta i kredibilitet menadžmenta}

Menadžmentu je dodijeljena ocjena 2. Menadžment se pokazao uspješnim u prodaji, te je tijekom posljednjih godina u knjizi narudžbi konstantno bilo 15-16 ugovorenih gradnji što osigurava kontinuitet proizvodnog procesa nekoliko godina unaprijed. Međutim, promatrajući rokove isporuke vidljivo je da su se zaredala značajna kašnjenja u isporuci ugovorenih brodova u 2016. i 2017. godini, a što je dovelo do golemog gubitka u 2107. godini, te je obzirom na ostvaren gubitak dovedeno u pitanje daljnje poslovanje grupe Uljanik d.d.

Tijekom 2016. i 2017. godine zaredala su se značajna kašnjenja u završetku i isporuci brodova, te je Uljanik bio primoran plaćati ugovorene penale. Isto je već tada ukazivalo na činjenicu da društvo nije i neće biti u mogućnosti proizvesti brodove sukladno ugovorenoj dinamici. Navedeno je značajno utjecalo na poslovanje društva u svim segmentima. Kasnilo se $s$ plaćanjem dobavljačima, bankama i kooperantima, kasnila je nabava materijala, te su kašnjenja u proizvodnom procesu bila sve češća i sve duža. Kao konačan pokazatelj ostvaren je gubitak u poslovanju 2016. godine uz njegovo višestruko povećanje u 2017. godini uz trend pogoršanja svih financijskih pokazatelja poslovanja. 
U revizorskom izvješću za 2016. i 2017. godinu navode se rezerviranja za očekivane gubitke u iznosu od 87 milijuna kn u 2016. do gotovo jedne milijarde kuna u 2017. godini. Obzirom na 15-ak ugovorenih brodova u knjizi narudžbi u 2017 godini, može se zaključiti da je u tom razdoblju ostvareno u prosjeku 70 - 80 milijuna kuna gubitka po brodu

Na dan 31.12.2016. u knjizi narudžbi grupe ULJANIK d.d. nalazila se ukupno 21 novogradnja s planiranim rokovima isporuke do 2018. godine. Na dan 31. prosinca 2017 godine $u$ knjizi narudžbi društva nalazilo se ukupno 14 novogradnji s planiranim rokovima isporuke. do 2020. godine. Iz navedenog se zaključuje da su u 2016. isporučena tek 3 broda, dok su u 2017. godini isporučena 4 broda umjesto ugovorenih 9. Već u 2016. godini je bilo evidentno kašnjenje u isporuci, te se moglo zaključiti da društvo neće biti u mogućnosti isporučiti 20 ugovorenih brodova do kraja 2018 godine. Isto tako Uljanik grupa je imala sklopljene ugovore po kojima su radovi započeli, ali nisu dovršeni i ugovore po kojima radovi još nisu započeli u vrijednosti 9 milijarde kuna u 2016. godini, odnosno 6,9 milijardi kuna u 2017. godini. Navedene vrijednosti ugovorenih brodova u tom periodu predstavljale su potencijalni gubitak za društvo u narednim godinama 2018 i 2019 godini, te obzirom na goleme ugovorene iznose, ujedno i veliku prijetnju njegovu poslovanju jer je evidentno da društvo nije više u mogućnosti poštovati ugovorene rokove gradnje.

\subsubsection{Vlasnička struktura društva}

Vlasničkoj strukturi društva dodijeljena je ocjena 4, budući se država koja posjeduje kontrolni paket dionica, smatra transparentnim, pouzdanim i sigurnim vlasnikom, te posjeduje instrumente i sredstva za pomoć društvu. Većinski vlasnici su mali dioničari (većinom zaposlenici društva), koji su se zajedno s državom pokazali inertni i površni u kontroli poslovanja društva odnosno same Uprave društva zbog čega je i dodijeljena ocjena 4.

Najveći dioničari Uljanika d.d. su mali dioničari koji drže $46,6 \%$ dionica, zatim država preko svojih zavoda i fondova drži $25,5 \%$, dok je najveći pojedinačni vlasnik grupa Adris d.d. s A $12,40 \%$ vlasništva.

Vidljivo je da mali dioničari posjeduje najveći udio u vlasništvu, te da na taj način ostvaruju najveći utjecaj na strateške odluke društva, te imaju i najveću odgovornost za poslovanje, ali da i država posjeduje preko $25 \%$ vlasništva (kontrolni paket) i na taj način predstavlja važnog dioničara bez kojeg se ne može donijeti niti jedna važna i strateška odluka društva kao npr. promjena statuta, smanjivanje i povećavanje temeljnog kapitala, opoziv članova nadzornog odbora, likvidaciju, spajanja li razdvajanja društva itd.

\subsubsection{Proizvodni kapaciteti i grana djelatnosti}

Proizvodnim kapacitetima i grani dodijeljena je ocjena 4. Grupa Uljanik d.d. posjeduje značajne proizvodne kapacitete, te koristi naprednu tehnologiju u pripremi i proizvodnji brodova. Najveća prednost grupe Uljanik d.d. je know-how zaposlenika koji se konstantno dokazuju na svjetskom tržištu u svim segmentima poslovnog procesa.. Uljanik d.d. već je dugi niz godina najuspješnije hrvatsko brodogradilište, a posljednjih nekoliko godina dokazali su se i proizvodnjom visoko složenih brodova kao polarnih kruzera. U zadnjih 20-ak 
godina društvo je godišnje proizvodilo u prosjeku 3 do 4 broda. $U$ pojedinim godinama proizvedeno je i 6 brodova, no to su bile manje složene gradnje i manje bruto tonaže.

Zaposlenici društva najvećim dijelom čine SSS, VKV, KV i PKV djelatnici. Rukovodeći kadar čine djelatnici VSS spreme. Uljanikovi stručnjaci projektiraju, konstruiraju i izrađuju sve vrste brodova, tako i za prijevoz nafte i naftnih prerađevina, za prijevoz rasutih tereta, kontejnera, kamiona vagona, automobila, putnika, te složenih jaružala i luksuznih kruzera. Stručnost zaposlenika Uljanika prepoznata je na europskom i svjetskom tržištu, te često zaposlenici Uljanika odlaze raditi u brodogradilišta diljem Europe.

Kontinuirano se investira u modernizaciju tehnološkog procesa, rezultat čega je proizvodnja najsloženijih jaružala i visoko luksuznih kruzera. Proizvodnom tehnologijom i vlastitim know-how-om društvo ne zaostaje za ostalim renomiranim svjetskim brodogradilištima. Brodogradnja zbog svoje specifičnosti spada u rizične gospodarske grane. Ustaljena je da praksa naručitelj najveći dio plaća nakon isporuke, dok samo manji iznos plaća prije i za vrijeme procesa proizvodnje. Za financiranje izgradnje broda brodogradilišta su primorana koristiti kredite banka.

\subsubsection{Tržište i tržišni položaj}

Tržišnom položaju dodijeljena je ocjena 3. U posljednjih 20-ak godina pojavila se konkurencija brodogradilišta iz Kine i Južne Koreje čime je dotadašnji tržišni udio grupe dodatno ugrožen. Naime, kineska i južnokorejska brodogradilišta sposobna su proizvesti brodove iz Uljanikova programa po znatno nižim cijenama, pa se kao takva sve više nameću na svjetskom tržištu.

Uvidjevši da značajno gubi tržišni udio s brodovima iz dotadašnjeg programa, Uljanik d.d. se u posljednjim godinama preorijentirao na gradnju visoko složenih brodova (jaružala i kruzera) kako bi zadržao određeni tržišni udio.

Tržište nabave za brod je specifično. Uljanik d.d. uglavnom naručuje materijal i opremu od istih renomiranih europskih dobavljača već dugi niz godina. Osnovna sirovina za brod je brodograđevni čelik koji se nabavlja u Češkoj, Ukrajini i Italiji.

Strateški smjer grupe Uljanik d.d. u zadnjih nekoliko godina je proizvodnja brodova visoke kvalitete i veće dodatne vrijednosti. Jaružala visokog stupnja složenosti i luksuzne brodove za krstarenje za kupce visoke kupovne moći. Tržište prodaje predstavlja u biti svjetsko tržište.

\subsubsection{Računovodstvo i izvješćivanje}

Računovodstvu i izvješćima je dodijeljena ocjena 4. Uljanik d.d. je kotirao na Zagrebačkoj burzi, te su sva financijska izvješća revidirana, transparentna i na vrijeme predavana. Ipak, postavlja se pitanje da li je dio golemog gubitka prikazan u 2017. godini mogao biti prikazan i u 2016. godini, obzirom da se radi o rezerviranjima za potencijalne gubitke. Revizorska izvješća za 2016. i 2017. godinu revidirana su od strane renomirane revizorske tvrtke PWC s mišljenjem s rezervom. 


\subsubsection{Pravna regulativa i sigurnost}

Pravnoj regulativa dodijeljena je ocjena 3. U Hrvatskoj je prisutna je ograničena pravna sigurnost koja je uvjetovana i učestalim promjenama regulative i dugim rješavanjem sudskih sporova. Također, u postupku su sudski sporovi iz radnih odnosa radi ozljeda na radu i smrtnih slučajeva s potencijalnim troškovima od 20 mil kn, a što u određenoj mjeri može utjecati na poslovni rezultat društva, ali nisu prijetnja poslovanju društva.

\section{Konačna ocjena boniteta društva Uljanik. d.d.}

Na primjeru grupe Uljanik d.d. procijenjen je bonitet zajedničkim korištenjem financijskih i kvalitativnih pokazatelja. U korištenom modelu, vrijednosti kvalitativnih pokazatelja i njihovi ponderi uvršteni su temeljem specifičnosti uvjeta poslovanja i poslovnog okruženja u Republici Hrvatskoj, te je model specifičan za utvrđivanje boniteta u hrvatskoj gospodarskoj praksi i kao takav nije relevantan za korištenje u drugim državama. Prilikom istraživanja i izrade modela korištena je metodologija i prilagođena matrica Standard \& Poor's Development of Corporate Rating (S\&P, 2021)

Do konačne ocjene boniteta u korištenom modelu dolazi se pomoću kvalitativne i financijske analize poslovanja. Model za utvrđivanje boniteta sastoji se od sljedećih elemenata, a što je prikazano u tablici br. 8: u prvom stupcu navedeni su najvažniji kvalitativni i financijski pokazatelji, u drugom stupcu dani su ponderi važnosti vrednovanja svakog pokazatelja, u trećem stupcu prikazani su kriteriji vrednovanja za svaki pojedini pokazatelj, četvrti stupac predviđen je za ocjenu svakog pokazatelja, peti stupac daje konačnu vrijednost za svaki pokazatelj, a predstavlja umnožak pondera i ocjene pokazatelja.

Zasebno su se ocjenjivali financijski i kvalitativni pokazatelji, te su se ocjene unosile u model kako bi se dobila konačna ocjena boniteta. Važno je naglasiti da je ukupna vrijednost pondera $100 \%$ i da se $50 \%$ odnosi na kvalitetne pokazatelje i isto tako se $50 \%$ odnosi na financijske pokazatelje. Konačna ocjena boniteta dobiva se množenjem pondera i dodijeljenih ocjena za svaki pokazatelj.

Tablica 8. Utvrđivanje konačne ocjene boniteta društva Uljanik d.d.

\begin{tabular}{|c|c|c|c|c|}
\hline Pokazatelji za vrednovanje & Ponder & Kriterij vrednovanja & Ocjena & Vrijednost \\
\hline \multicolumn{5}{|l|}{ Kvalitativni pokazatelji } \\
\hline Kvaliteta menadžmenta & $13,00 \%$ & 5 (izvrstan) - 1 (iznimno loš) & 2 & 0,26 \\
\hline Vlasnička struktura & $10,00 \%$ & 5 (izvrstan) - 1 (iznimno loš) & 4 & 0,40 \\
\hline Tržište/tržišni položaj & $8,00 \%$ & 5 (izvrstan) - 1 (iznimno loš) & 3 & 0,24 \\
\hline $\begin{array}{l}\text { Proizvodni kapaciteti } \\
\text { i grana djelatnosti }\end{array}$ & $9,00 \%$ & 5 (izvrsna) - 1 (iznimno loša) & 4 & 0,36 \\
\hline Računovodstvo, izvješćivanje & $5,00 \%$ & 5 (izvrsna) - 1 (iznimno loša) & 4 & 0,20 \\
\hline Pravna regulativa i sigurnost & $5,00 \%$ & 5 (izvrsna) - 1 (iznimno loša) & 3 & 0,15 \\
\hline $\begin{array}{l}\text { Kvantitativni pokazatelji } \\
\text { Povrat na kapital }\end{array}$ & $11,00 \%$ & $\begin{array}{l}>35 \% \ldots \ldots \ldots \ldots \ldots \ldots \ldots \ldots \ldots \ldots \ldots \ldots \ldots \ldots \\
>\end{array}$ & 1 & 0,11 \\
\hline
\end{tabular}




\begin{tabular}{|c|c|c|c|c|}
\hline Pokazatelji za vrednovanje & Ponder & Kriterij vrednovanja & Ocjena & Vrijednost \\
\hline Profitabilnost: ebit/prodaja & $8,00 \%$ & 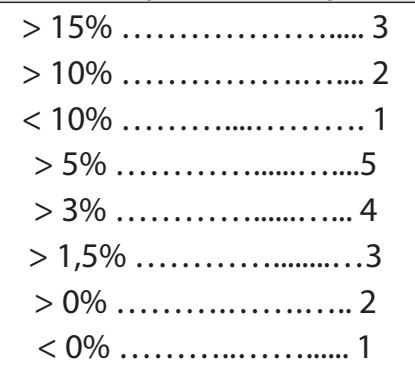 & 1 & 0,08 \\
\hline $\begin{array}{l}\text { Novčani tok iz poslovnih } \\
\text { aktivnosti/prodaja }\end{array}$ & $10,00 \%$ & 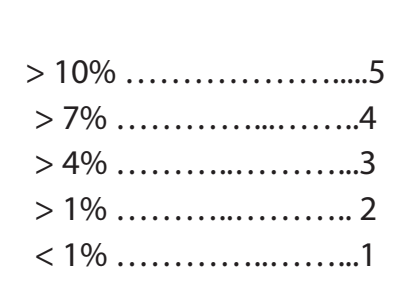 & 1 & 0,10 \\
\hline Odnos duga i kapitala & $7,00 \%$ & 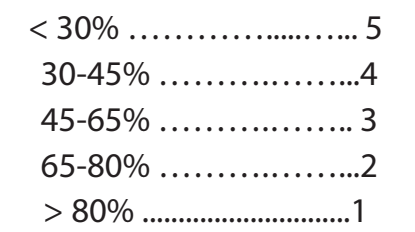 & 1 & 0,07 \\
\hline Likvidnost & $9,00 \%$ & 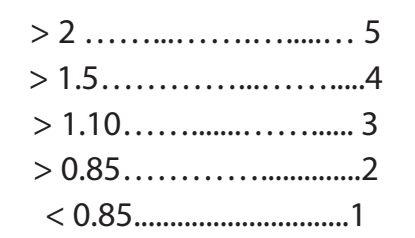 & 1 & 0,09 \\
\hline Pokriće kamata & $5,00 \%$ & $\begin{array}{l}> \\
> \\
>\end{array}$ & 1 & 0,05 \\
\hline $\begin{array}{l}\text { Suma vrijednosti } \\
\text { pokazatelja }\end{array}$ & $100 \%$ & & & 2,11 \\
\hline
\end{tabular}

Izvor: prilagođeno prema Vareško A. (2008), Utvrđivanje modela sinergične primjene sustava financijskih i kvalitativnih pokazatelja pri ocjeni boniteta trgovačkog društva, magistarski rad,

Ekonomski fakultet Pula, Pula

\section{Uljanik d.d. dobio je konačnu ocjenu boniteta od 2,11.}

Iz financijske analize za obje promatrane godine vidljivo je da su gotovo svi financijski pokazatelji dobili najnižu ocjenu, a da su imali i negativan trend. Niske ocjene za isto razdoblje dane su i većini kvalitetnih pokazatelja što je samo potvrdilo ozbiljnost situacije u kojoj se društvo tada nalazilo. Obzirom na loše financijske i kvalitetne pokazatelje i konačna ocjena 
je također vrlo loša, te ukazuje na velike propuste u poslovanju i nepoduzimanje konkretnih i odlučnih mjera za očuvanje poslovanja.

Dok kod financijskih pokazatelja nema velikih iznimki, već su svi loši, promatrajući kvalitetne čimbenike vidljivo je da su menadžment i vlasnička struktura dobili vrlo niske ocjene, dok su ostali kvalitetni pokazatelji dobili bolje ocjene.

Gotovo svi financijski pokazatelji poslovanja dobili su najniže ocjene. Isto tako prisutan je i trend pogoršanja gotovo svih financijskih pokazatelja u promatranom razdoblju odnosno u 2017. godini u odnosu na prethodnu 2016. godinu.

Može se zaključiti da su se već u 2016. godini po svim pokazateljima mogle potvrditi velike poteškoće u poslovanju društva, te je isto ukazivalo na nužnost promptnog poduzimanja mjera za rješavanje evidentnih poteškoća u poslovanju (gubitak, nelikvidnost, nepoštivanje ugovornih rokova i dr.) od strane uprave, a što je u konačnici dovelo do vrlo loše ocjene menadžmenta. Vlasnička struktura predstavljala je određenu sigurnost, obzirom na kontrolni paket dionica države koja je imala snagu i sredstva da se aktivno uključi u rješavanje nastalih poteškoća. Međutim i mali dioničari i država, su se kroz nadzorni odbor i skupštinu društva pokazali nezainteresirani za analizu poslovnih poteškoća, te nisu reagirali pravovremeno s ciljem rješavanja istih.

Grupa se unatoč pojavi konkurentnijih brodogradilišta iz Azije uspjela održati na iznimno zahtjevnom svjetskom tržištu brodogradnje i to preorijentiranjem na visoko složene gradnje.

Sva financijska izvješća izrađuju se i predaju nadležnim institucijama u roku i potvrđena su od strane revizije, ali je isto tako istaknuto mišljenje revizora s rezervom zbog u 2016. i 2017. godini .

Vode se sudski sporovi, te predstavljaju određeni potencijalni trošak.

Na primjeru Grupe Uljanik d.d. može se uočiti kako u samo nekoliko godina može propasti stogodišnja tradicija poslovanja. Najodgovornija za propast društva je sama Uprava jer nije pravovremeno krenula rješavati ozbiljne probleme koji su se pojavili u 2016. godini. Analizirajući samo financijske pokazatelje za 2016. godinu, moglo se vrlo lako zaključiti da je društvo u velikim poslovnim problemima, a koji postaju golemi u 2017. godini.

Uzimajući u obzir i kvalitativne elemente posebice Menadžment, moglo se utvrditi da najviša upravljačka struktura društva ne poduzima pravovremene i odlučne mjere s ciljem smanjivanja nastalog gubitka u 2016., a posebice u 2017. godini. Isto tako, analiza djelovanja nadzornog odbora i skupštine društva, kao tijela vlasnika, ukazuje na njenu inertnost i površnost u zahtijevanju odlučnih koraka u rješavanju problema od strane Uprave.

Kako su i financijska i kvalitativna analiza pokazatelja vrlo loše bodovane, evidentno je da je i konačna ocjena boniteta društva vrlo loša i da je ukazivala na nužnost donošenja žurnih mjera za očuvanje poslovanja.

\section{Zaključak}

U današnjoj poslovnoj praksi prilikom sklapanja poslovnog odnosa partneri sve češće međusobno provjeravaju bonitet kako bi bili što sigurniji u pouzdanost poslovnog odnosa. Jedna od prednosti procjene boniteta je upravo postizanja što boljeg ugleda na tržištu odno- 
sno pouzdanosti pri sklapanju poslovnih odnosa, ali isto tako važno je i pravovremeno prepoznati potencijalne rizike, te na vrijeme poduzeti potrebne mjere za njihovo uklanjanje.

Ovisno o specifičnostima svakog pojedinog tržišta i svakog pojedinog društva, potrebno je pri utvrđivanju boniteta uzeti u obzir i druge čimbenike koji bitno utječu na poslovanje pojedinog društva, a nisu neposredno vezani za financijska izvješća. U korištenom modelu u ovom radu navedeni su najvažniji kvalitativni i financijski pokazatelji, čiji zajednički zbroj ponderiranih vrijednosti daje konačnu ocjenu boniteta poslovnog subjekta.

Iz provedene analize poslovanja i utvrđivanja boniteta proizlazi da je društvo u promatranom razdoblju, usprkos ozbiljnim problemima u proizvodnom procesu i gomilanju značajnog gubitka, imalo još uvijek zavidnu tržišnu poziciju i bilo prepoznato u svijetu kao kvalitetno brodogradilište, te je raspolagalo značajnim proizvodnim kapacitetima, modernom tehnologijom i zajedno s kvalitetnim i stručnim kadrom bilo u mogućnosti sagraditi i najsloženije brodove na tržištu.

Zaključak je da je za nastalu situaciju najodgovornija uprava društva koja nije optimalno iskoristila proizvodne kapacitete društva odnosno pogriješila je u strategiji prodaje ugovarajući više brodova od realnih proizvodnih mogućnosti društva, a zbog čega je društvo bilo primorano plaćati velike penale. Dodatna odgovornost Uprave leži u činjenici da nije pravovremeno reagirala na prepoznate probleme i nije ranije zatražila pomoć od države kao suvlasnika koja posjeduje kontrolni paket dionica i koja je jedina u tom trenutka mogla pomoći.

Pored Uprave odgovornost za loše rezultate imaju i vlasnici koji su kroz svoja tijela površno i neadekvatno pratili i kontrolirali poslovanje društva, te je dozvoljeno da gubitak eskalira u 2017. godini.

Navedena analiza ukazuje u konačnici na važnost redovite procjene boniteta kako bi se pravovremeno prepoznali rizici poslovanja, te poduzele potrebne, a često i odlučne (teške) mjere za smanjivanje i otklanjanje poslovnih rizika. U protivnom može se dogoditi kao na primjeru grupe Uljanik d.d. da u samo nekoliko godina propadne društvo koje je uspješno poslovalo cijelo stoljeće.

\section{LITERATURA}

1. Altman E.I. (2008). Revisiting Credit Scoring Models in a Basel 2 Environment. NYU working papers, 02 (11), str. 1-37

2. ECB (2010). Beyond RoE: How to measure bank performance. Appendix to the report on EU banking structures. dostupno na: https://www.ecb.europa.eu/pub/pdf/other/beyondroehowtomeasurebankperformance201009en.pdf (pristup 15.02.2021.)

3. Grunert, J., Norden, L., Weber, M. (2005). The role of nonfinancial factors in internal credit ratings. Journal of banking \& Finance, 29 (2), str. 509-531.

4. Leko, V. (1996). Procjena boniteta trgovačkog društva. Zagreb: Masmedia

5. Pavković, A., Vedriš D. (2011). Redefiniranje uloge agencija za kreditni rejting u suvremenom financijskom sustavu. Ekonomska misao i praksa, 1, str. 225-250

6. S \& P Global. dostupno na: https://www.standardandpoors.com/en_US/web/guest/ ratings/ratings-actions (pristup 05.02.2021.) 
7. S \& P Global ratings. dostupno na: https://www.spratings.com/scenario-builder- portlet/ pdfs/CorporateMethodology.pdf (pristup 25.02.2021.)

8. Tintor, Ž. (2020). Analiza financijskih izvještaja u funkciji donošenja kvalitetnijih upravljačkih odluka. Obrazovanje za poduzetništvo: znanstveno stručni časopis o obrazovanju za poduzetništvo, 10 (1), str. 84-103

9. https://www.uljanik.hr (pristup 10.01.2021.)

10. Vareško A. (2008). Utvrđivanje modela sinergične primjene sustava financijskih i kvalitativnih pokazatelja pri ocjeni boniteta trgovačkog društva. Magistarski rad. Pula: Sveučilište Jurja Dobrile

11. Žager, K., Žager, L. (1999). Analiza financijskih izvještaja. Zagreb: Masmedia

12. Žager, K., Mamić Sačer, I., Sever, S., Žager, L. (2008). Analiza financijskih izvještaja 2. prošireno izdanje. Zagreb: Masmedia

\section{Summary}

\section{EVALUATION OF CREDITWORTHINESS THROUGH THE CREDIT SCORE MODEL BY SYNERGIC USE OF FINANCIAL AND QUALITATIVE INDICATORS}

It is well known that in the Croatian economy very little attention is paid to business analysis and business risk management. Also, incompetence and inadequate expertise of top management, as well as superficial and insufficiently professional supervision of business by companies' owners, continuously generate problems with liquidity, over-indebtedness, and losses within Croatian companies. Failure to (timely) address these problems is in essence the cause of a large number of bankruptcies and liquidations of business entities, which ultimately produces serious problems for the Croatian economy in general. In this paper, business analysis and the analysis of business risks of the Uljanik d.d. group. during the period from 2016. to 2017. will be evaluated in order to determine the creditworthiness of the company at that time, respectively before the announcement of the company's bankruptcy in 2019. This paper will try to determine whether the difficulties in business could be promptly identified and whether the company's management structure in the mentioned period could react faster and more decisively based on the assessment of the company's creditworthiness and the knowledge gained during the analysis. The optimal choice of financial and qualitative indicators was used in the evaluation of creditworthiness by which it is possible to make a more reliable assessment of creditworthiness taking into account internal and external factors that affect the company's operations. In the used credit score model, the final credit rating is determined by synthesis and common use of financial and qualitative indicators and provides comprehensive and credible information about the business entity and its business risks and in that way allows the correct business decisions to be taken on time.

Keywords: Uljanik, creditworthiness, financial indicators, qualitative indicators, business analysis. 